\title{
Петрусева Н.А. Булез и IRCAM
}

Аннотация: Предметом исследования является деятельность ведущего композитора, теоретика, полемиста, педагога и дирижера Новой музыки Пьера Булеза, приведиая к возникновению Института исследования и координации акустики и музыки (IRCAM, Париж, Центр Ж. Помпиду). Рассмотрены контекст и этапы деятельности Булеза, три типа музыкальных учреждений (обучающие, исполняющие и исследовательские), структура IRCAM; его статья "Технология и композитор», ставшая манифестом IRCAM; булезовская интерпретация тотального сериализма, период отрицания предшествующей (ближайшей) традиции и переход к периоду «синтеза». Используется комплексный метод исследования как сочетание сравнительной компаративистики, структурно-музыкальных методов и элементов социальных методов. Новизна исследования заключается в попытке очертить грани опыта антропосоциологического исследования на примере социокультурной деятельности Пьера Булеза. В качестве вывода прочерчивается единая линия развития в деятельности Булеза, которая начинаясь непосредственными проблемами эстетики, музыкального материала, языка и вопросами новой концепции формы, через проблемы восприятия и исполнения музыки приходит кмузыкальным учреждениям.

Ключевъе слова: Периоды деятельности Булеза, Институт IRCAM, Новая музыка, постсериальный модернизм, «векторная композиция», типы музыкальных учреждений, обучающие, исполняющие Новую музыку, исследовательские, структура и манифест.

Review: The subject of the research is the activity of a leading composer, theorist, polemist, teacher and conductor of New Music Pierre Boulez whose activity led to the foundation of Institute for Research and Coordination in Acoustics/Music (IRCAM, the Centre Pompidou in Paris). Petruseva analyzes the environment and stages of Boulez' creative activity, three types of musical establishments (training, performing and research establishments), IRCAM structure; Boulez' article 'Technology and the Composer' that became the manifesto of IRCAM; Boulez' interpretation of the total serialism, denial of preceding (nearest) tradition and transition to the period of 'synthesis'. The researcher uses an integrated research method that combines comparative studies, structural musical methods and elements of social methods. The novelty of the research is caused by the fact that the author tries to outline the borders of anthroposociological research based on the example of Pierre Boulez' sociocultural activity. As a conclusion, the author describes the single line of Boulez' activity that starts with immediate problems of aesthetics, musical material, language and New Music concept and comes to musical establishments through the problems of perception and music performance.

Keywords: Post-serialistic modernism, 'vector composition', types of musical establishments, teaching, performing New Music, research-related, structure and manifesto, New Music, IRCAM (Institut de Recherche et de Coordination Ac, stages of Boulez' creative activity.

Композитор - это глаз, которьци ухо управляет.

П. Булез

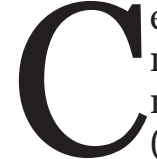
егодня роль антропосоциологического познания существенна, поскольку оно становится «вторым входом» (Ж. Деррида[1]), необходимым для всякого научного познания. Как обнаружить социальное бессознательное в научном и художественном сознании? Как уловить и расшифровать проявления общества в наблюдателе-художнике? Уяснение своеобразных черт социокультурной деятельности Пьера Булеза путем сравнительного рассмотрения трех периодов его деятельности проливает не- который свет на саму культурно-социальную метасистему, которую музыка как язык предполагает и в которой она обретает смысл.

Булез рано имел потребность не кодифицировать то, что находилось посредине развития, но точно добираться до сути актуальных механизмов изобретения. Как лектор Дармштадтских курсов, которые частично опубликованы (в 1963, 1980 и 2000 гг.)[2], он давал общую ориентацию по поводу насущных проблем композиции и указывал, что можно делать в современной ситуации, как 
расширить возможности, унаследованные от наших непосредственных предшественников. С 1974 по 1991 гг. Булез является директором IRCAM (Institut de Recherche et Coordination Acoustique/Musique / Институт исследования и координации акустики и музыки).

Рассматривая жизнь Пьера Булеза (р. 1925) и его деятельность, исследователи выделяют две стратегии, которые позволили ему достичь большого культурного полномочия, и привести культурную столицу Париж к необходимости основания IRCAM. Каждая из этих стратегий - непревзойденная (за исключением нескольких главных фигур послевоенного авангарда) комбинация композиционных и исполнительских навыков в разных, но взаимосвязанных областях его деятельности: 1) как композитора и дирижера, 2) как теоретика, автора, полемиста и педагога. Этим способом он управлял каждым аспектом музыкального диалога: своим сочинением, звуковым производством, но также и условиями своего сочинения - его исполнением, теоретизацией, распространением через образование, и таким образом, его легитимизацией. Булез был активным в культурной и национальной политике на самых высоких международных уровнях. Он, утверждает Борн, «имел ведущее значение в соединении Франции с международными потокам музыки, объединяя, таким образом, национальный и международный престиж» $[3]$.

С 1973 по 1984-е гг. карьера Пьера Булеза может быть разделена на три фазы[4]. Первая - его восхождение к известности, от середины 1940-х к началу 1960-х гг. В конце 40-х и вначале 50-х гг. Булез написал полемические статьи против влиятельных музыкальных учреждений. Его обвинения пали на многие главные фигуры: Шёнберга, Стравинского, Мессиана. Обвинив Шёнберга в печально известном эссе «Шёнберг мертв» (1951) в неудаче осуществить революцию, спровоцированную серийностью, в его обращении к устарелым романтичным формам, Булез объявил: сериализм - единственный для музыки путь развития. Это положило основу тому, что доминирующим в 1950-е гг. стало авангардное развитие, тотальный сериализм, который возник из расширения принципа структурной организации высот на измерения других параметров звука. Мышление параметрами, заимствованное из естествознания, позволяло рассматривать звук как сложный сплав его физических качеств (параметров). Пара- метры звука рассмотрены в трактате Булеза «Мыслить музыку сегодня» (1963/1971):

1) абсолютная высота, относительная величина;

2) длительность / пропорции, временной объем, темп (хронометрически);

3) абсолютная громкость (коэффициенты), относительная громкость (значения), динамический профиль;

4) тембр (наиболее неисследованный и экспериментальный параметр звука);

5) пространственная диспозиция (в частности, область использования компьютерных технологий).

Согласно Булезу, принцип взаимодействия различных составляющих композиции необходимо осуществлять «в векторной композиции, когда каждый вектор в соответствии с природой своего материала имеет свою собственную структурацию»[5].

Так, относительная высота в Новой музыке предполагает соотнесенность звуков в локальных структурах, которые многообразны: серии, ряды, спектры, масс-блоки, комплексы, сет-комплексы, «многопараметровые формулы», «звуковые панели» и т. д. У Булеза локальные структуры высотного параметра - результат последовательного цикла «операций» (тер. Малларме) по препарации серии: сегментация числовым рядом, ротация, образование простых групп, гармонических областей, мультипликация, т. е. образование сложных групп мобильной плотности путем сверналожения, редукция, транспозиция по избранному модулю, совокупность гармонических полей, объединенных в «созвездие-констелляцию»[6]. Благодаря технике мультипликации высот (и ритмов), впервые использованной в «Молотке без мастера» (первое исполнение в Баден-Бадене в 1955 году), Булез достиг своего стиля, соединив немецкий конструктивизм и чисто французский, идущий от Дебюсси и Мессиана, декоративно-орнаментальный стиль. В этом смысле «Молоток ...» является для Булеза знаковым произведением.

Параметр динамического профиля предполагает его соотнесенность с длительностями и динамическим объемом. В пьесе может преобладать резкая «стаккатная» динамика («Klavierstück 7» Штокхаузена), или чередование штрихового пуантилизма, оазисов пролонгированных статичных состояний и звуковых смесей, в которых внутренняя жизнь отзвука и движения проникают одно в другое («Allegro sostenuto» Лахенмана, 1989). 
В трактовке темпа все композиторы, вышедшие из класса Мессиана (и их последователи) используют сложные темповые шкалы, темповую драматургию (влияние Стравинского) и темповый контрапункт («Группы для трех оркестров» Штокхаузена, «Lied для скрипки и фортепиано» австрийского композитора Б. Фуррера и др.). Так, в «Посланиэскизе» для семи виолончелей (Messagesquisse, 1976) Булеза движение темпа вбирает качественную множественность переходов (мыслимых как звенья геометрической прогрессии) и «разрывов»[7].

В 1950-е гг. группа французских композиторов все более сближалась с философскими идеями Ж.П. Сартра, К. Леви-Стросса и М Фуко. Под воздействием идей ведущих ученых - Ж. Пиаже, Ж. Моно, Ж. Лакана - Булез начинает оперировать методами структурного анализа. Идея многопараметровости звука высвобождала невероятные творческие энергии, открывала неизвестные до тех пор звуковые миры. Описав свое лидерство в тотальном сериализме как «час нуль», Булез осуществил полный разрыв в области истории музыки: произошел кризис, требующий нового языка. Этот пункт остается центральной темой всей его деятельности.

Между 1954 и 1967 годами Булез руководил и дирижировал концертами Мюзикаль Домэйн, время с конца 1940-х до начала 1960-х гг. было его самым плодотворным и успешным как композитора. В течение этого же периода он обратился за границей к главным европейским центрам авангарда. Первый центр возник из его близких отношений с директором немецкого радио в Баден-Бадене, Генрихом Штробелем. Штробель руководил фестивалем новой музыки в Донаушингене, где впервые прозвучали многие композиции Булеза и Штокхаузена. Другим центром были Дармштадтские ежегодные международные Летние курсы новой музыки, которые стали известны как объединяющий пункт для нового послевоенного европейского авангарда. Адорно, преподававший там регулярно в течение 1950-х гг., имел влияние на Булеза, и отголоски его мысли очевидны в текстах Булеза. Традиции немецкой музыки и философии имели сильное влияние на Булеза, и он думал о Германии как о втором доме. Булез стал одним из главных преподавателей в Дармштадте, а в начале и в середине 1950-х годов - ведущей фигурой европейского авангарда[8]. Мировую известность композитору принесли кантата «Солнце вод» и Вторая фортепианная соната, впервые исполненная самим автором в Дармштадте в 1952 году[9]. Его лекции 1960-х, изданные как «Мыслить музыку сегодня», объединили его теорию нового музыкального языка, основанного на тотальном сериализме. Заметим: важные композиционные импульсы происходили как раз из противопоставления «тотального сериализма» и «полной случайности» (Aleato$r i k)$; именно эти принципы стали определять удавшиеся сериальные композиции.

Вторая стадия деятельности Булеза (начало 1960-х по1977-й гг.) представлена значительным расширением его поля деятельности и все более и более престижной международной работой в качестве дирижера различных крупных оркестров, которая в итоге завершилась созданием IRCAM.

В течение двух лет он стал главным дирижером двух всемирных ведущих оркестров - Симфонического оркестра ВВС и НьюЙоркской филармонии; в Лондоне он успешен как дирижер. В Европе Булез достиг одной из самой всемирно престижной оперы, дирижируя в Байройте, в доме Вагнера, он исполнил весь цикл «Кольца» в 1976 г. по случаю его сотовой годовщины. Булез с тех пор остался близко связанным с Байройтом, и он часто вызывает сравнение с Вагнером.

Булез также был вовлечен в несколько высокопрофессиональных французских культурных политических споров. В 1964 г. Мальро, тогда министр культуры, устанавливал полномочия относительно французской музыки; это была прелюдия к созданию нового направления музыки. Борьба за власть велась между двумя фракциями: одна во главе с композитором Ландовски (Landowski), другая - c Булезом, который разработал план относительно главных реформ. Мальро отклонил идеи Булеза, и в газетной статье «Почему я говорю «нет» Мальро» (Pouquoi je dis «non» a Malraux), опубликованной в «Le Nouvel Observateur» (25. 5. 1966), Булез резко критиковал министра и объявил, что он впредь «бастует» против официальной организации французской музыки. Непосредственно после выступления во французской прессе, Булез сокращает связи с Domaine, парижской Оперой, французскими оркестрами и входит в самоналоженное изгнание в Германии. (Главная критика Булеза была направлена на то, что администрация музыки не должна быть в руках «неудавшихся композиторов» - Ландовски, Мийо и других от конкурирую- 
щей фракции - но в руках специализированных администраторов[10]. Меньше чем через десятилетие, Булез предложил себя в качестве директора IRCAM.) В течение 1950-х и 1960-х гг. Германия, прежде всего, но также Великобритания стали альтернативными музыкальными, интеллектуальными и политическими убежищами для Булеза. Эффекты от таких споров, «разделили общественное мнение» и сделали Булеза, утверждает Борн, «знаменитой и более спорной фигурой во Франции»[11], также усилили его международные связи и репутацию.

Добавим, что эстетические подходы, которые подверглись критике Булеза, включают неоклассицизм, особенно в его ранних статьях (и письмах), постмодернизм и так называемое движение «подлинности» в более поздние годы. Во всех этих подходах, аргументирует Булез, история становится средством защиты от реальных проблем дня. В тексте «Стравинский: стиль или идея? Хвала амнезии» [12] Булез связывает неоклассицизм с «эклектикой и мрачным гедонизмом»: «Может ли “универсальный” язык существовать сейчас? Средствами неоклассицизма? Конечно, необходимо отвергнуть его. Редко смущаясь движением, настолько сбивающим с толку, насколько это возможно - от Баха к Чайковскому, от Перголези к Мендельсону, от Бетховена к ренессансной полифонии, - неоклассицизм очертил шаги по направлению к эклектике, жалкой несостоятельности какого-либо языка, с рождения склонного к интеллектуальной лености, приводящей его к его собственному концу - или, если хотите, к мрачному гедонизму»[13]. Двадцать лет дирижируя музыкой Стравинского, Булез видел это поколение «лучше, чем самого себя»[14]. Вероятно, не без влияния критики Булеза Стравинский, оставив неоклассицизм и став аскетом, вступил в свой третий серийный период, ориентиром для которого послужила, как известно, музыка А. Веберна, наиболее радикального представителя Нововенской школы.

Третья стадия деятельности Булеза, с 1977 г., является периодом после его возвращения в Париж для руководства IRCAM.

На обеде в Елисеевском дворце в 1970 г. Жорж Помпиду предложил Булезу возможность проектировать новый исследовательский центр музыки[15]. В течение 1977 г. с массивным рядом парижских концертов под названием «XX век», объявляющих об открытии IRCAM, возвращение Булеза привлекло большое общественное внимание: 70 концертов прошли в течение года в разных местах Парижа! IRCAM стал главным академическим утверждением Булеза.

После открытия IRCAM карьера Булезадирижера продолжалась, будучи связанной в основном с ансамблем InterContemporain, ocнованным Булезом в 1976-1977-м гг. и предназначенным для исполнения современной и Новой музыки. Основу репертуара Булеза составляют сочинения композиторов XX века - от Малера до Лигети и Штокхаузена[16]. Однако несколько комментаторов отметили: с середины 1960-х гг. композиционная продукция Булеза резко снижается. Это привело к предложению, что его обязательства в отношении IRCAM и дирижерской деятельности захватили его полностью, но дезинформировали его как композитора. Начиная с возникновения IRCAM, единственной главной композицией Булеза, вовлекающей компьютерную технологию музыки, была крупномасштабная композиция «Респонсорий».

В «Респонсории» (Répons), исполненном впервые 18 октября 1981 г. ансамблем Интерконтемпорэн (дирижировал автор), использована развитая в IRCAM технология[17]. Работа над «Répons» продолжалась до 1984 г.: существование других редакций указывает на произведение открытой формы («work in progress»). Название композиции отсылает к респонсорным формам григорианского хорала, в котором соло певца противопоставляется хору. В этой простой средневековой форме содержится несколько идей, которые проходят через всю композицию Булеза: простая исходная музыкальная идея и ее пролиферация (внезапное разрастание музыкальной ткани, техника, характерная для постсериального периода Булеза), противопоставление сольного и коллективного исполнения, движение звука в пространстве.

Инструментальный ансамбль и дирижер размещены на сцене в центре зала. Солисты расположены равномерно по краю зала, заполненного аудиторией, которая находится между солистами и инструментальным ансамблем. Звуки солистов трансформированы электронно-акустической системой, созданной компьютером (использует анализ, изменение и опространствление звука солистов) и шестью усилителями; звуки ансамбля не трансформированы[18].

Булез входит в историю мировой музыкальной культуры как несравненный дири- 
жер крупнейших постановок «Парсифаля» (1965) и оперной тетралогии «Кольцо Нибелунгов» (1976) Вагнера в Байройтском театре, опер «Пеллеас и Мелизанда» Дебюсси (1969, Лондон, театр Ковент-Гарден), «Лулу» Берга (1979, Париж), «Моисей и Аарона» Шёнберга (1996, Зальцбургский фестиваль, Нидерландская опера, Амстердам). В настоящее время Булез, сделав Париж центром современной музыки и во многом определив направление композиторского поколения не только во Франции, но и во всей Европе, имеет немало учеников и последователей. При участии Булеза была основана Люцернская академия (2004) для занятий с музыкантами и композиторами, для пропаганды и распространения музыки XX и XXI вв. 23 августа в рамках ежегодного летнего фестиваля состоялся концертный марафон. Студенты Академии и ансамбль InterContemporain дали в этот день 11 концертов из произведений Булеза, а также новых сочинений Хайнца Холлигера, Дьёрдя Куртага, Тода Маковера, Кристиана Мэйсона, Маттиаса Пинчера и Вольфганга Рима.

Сегодня вырисовывается линия развития в деятельности Булеза, которая, начинаясь непосредственными проблемами эстетики, музыкального материала[19], языка и вопросами новой концепции формы (мобильной открытой формы), через проблемы восприятия и исполнения музыки[20] приходит к музыкальным учреждениям. Булез выделяет три типа учреждений.

Первый тип Булез определят, как обучающее учреждение. Его опыт в учреждениях подобного типа включает его преподавание в Дармштадтской летней школе (Darmstadt Summer School), Базельском университете (Basel University), в университете Гарварда (Harvard University) и Коллеж де Франц (College de France). Он преподавал в Дармштадте в 1956, 1959, 1960, 1961 и 1965 гг. В Базельском Университете (1960-63) он вел анализ и композицию, анализируя такие произведения как «Воццек» Берга (1914-22), «Группы» Штокхаузена (1955-57). К сожалению, ни один из материалов этих курсов не был издан. В 1963 г. Булез уехал из Базеля, приняв приглашение стать профессором Гарварде. Его Гарвардские лекции были изданы в двух частях как «Необходимость эстетической ориентации» (Nécessité d'une orientation esthétique) (1963) и «Необходимость эстетической ориентации II» (Nécessité d’une orientation esthétique II) (1963). В 1976 он стал профессором в Кол- леж de Франц. Опыт Булеза-педагога обобщен в его статьях «Дисциплина и коммуникация», «Разговор учителя».

Второй тип учреждения - исполняющие учреждения: они связаны со средствами исполнения музыкального наследия и современной музыки. Хотя его первая профессиональная деятельность внутри данного типа учреждения была должностью музыкального директора Compagnie Renaud-Barrault между 1946 и 1956 гг., его первый опыт управления исполняющим учреждением был связан с концертами Domaine Musical. Булез непосредственно столкнулся здесь с проблемами, с которыми сталкиваются исполнители новой музыки, в частности, с потребностью приспособить виртуозность исполнителей к требованиям новых работ. Его значительную работу дирижера в течение конца 1960 и 1970-х гг. рассматривают, как попытку решить проблему существующего разрыва между композитором Новой музыки и аудиторией.

Третий тип учреждения, которое описывает Булез, является учреждением исследования. IRCAM представляет первый пример такого типа учреждения, где Булез достигает возможности институциализировать свою концепцию музыки. Многие учреждения, посвятившие себя исследованию музыки, не были в отличие от IRCAM материально автономны и не были полностью посвящены этой области. Некоторые из них сформировали Булезовское видение IRCAM. Это, конечно, его работа в студиях в Париже (RTF) и Кёльне (Westdeutscher Rundfunk), которая, должно быть, предоставила ему ценные уроки. В 197576 гг. под влиянием первого научного директора IRCAM, «отца компьютерной музыки», Макса Мэтьюса моделью для первоначальной инфраструктуры IRCAM стал Центр Стэндфордского университета компьютерного исследования в музыке и акустике (CCRMA)[21]. Другое возможное влияние на его концепцию IRCAM - параллель между учреждением Булеза и Вагнеровским видением Байройта. Давид Вальтерс проницательно замечает, что «самая поразительная модель» для IRCAM - Центр Жоржа Помпиду и Баухаус: «Булез говорил об этой параллели до тех пор, пока художественное сообщество и междисциплинарный подход, установленный в Баухаусе, не осуществились в IRCAM[22]. Добавим, что по первоначальному замыслу Булеза IRCAM должен был возникнуть в Дармштадте в качестве научного института по исследованию 
возможностей новой музыки, который вошел бы в Международное общество Макса Планка.

Открытие и функционирование IRCAM способствовало необычайному росту центров «исследования музыки», которые стремились к взаимосвязанному научному исследованию и технологическому развитию в сфере музыки. Согласно статистическим данным Борн (до 1984), в 1973 г. центров было только два, в 1975 - четыре, в 1977 г. в дополнение к IRCAM их стало шесть, к 1982 - семнадцать, и к 1984 г. двадцать пять центров[23].

Здание Центра Ж. Помпиду (фото 1) стало манифестом нового стиля неомодернистского архитектора Ричарда Роджерса (Rogers), в котором большинство инженерных систем (водоснабжение, отопление, вентиляция, лестницы и лифты) были выведены в экстерьер, оставляя свободными интерьер и внутренние помещения. (В то время критики отнеслись к дизайну «наизнанку» настороженно; однако сегодня Центр Помпиду считается достопримечательностью.)
Центр, как известно, называют Бобур, и он напоминает «многослойный пирог». В нем размещаются 6 уровней: о уровень - Детская галерея, гардероб, билетные кассы, почтовое отделение, книжный магазин; 1 уровень - кинотеатр, кафе, мебельный магазин «Прэнтан», 2-3 уровни - огромная библиотека (кино, видео, аудио), кафе, 4-5 уровни - «Национальный музей современного искусства», 6 уровень - временные выставки, книжный магазин, смотровая площадка (фото 2), ресторан.

Национальный музей современного искусства (MNAM): вмещает 40000 экспонатов[24]. Перечислю название некоторых залов: «Об истоках музея» (1 зал), «Фовизм: Дюран, Дюбо, Вламинк» (3), «Кубизм» (5), «Лежер, Лоуренс, Брак» (7), «Дебюты абстракционизма» $(8,9)$, «Дада» (13), «Фигурационизм после 1914» (16), «Джакометти» (23), «Новые реалисты» (33) и т. д.

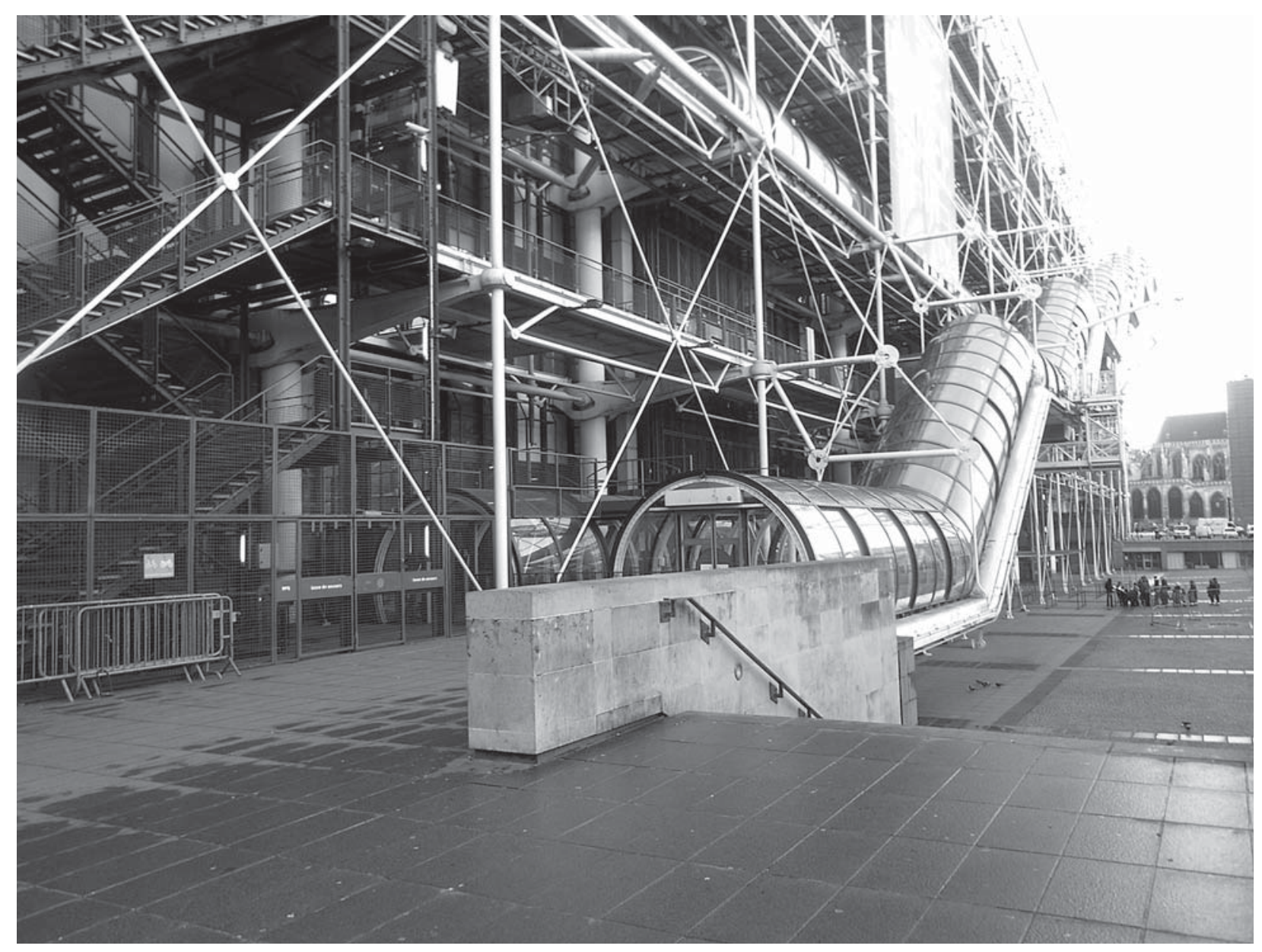

Фото 1. Центр Жоржа Помпиду (Фото 1-4 Н. Петрусевой). 
Фото 2.

Центр Ж. Помпиду. Смотровая площадка (6 уровень)

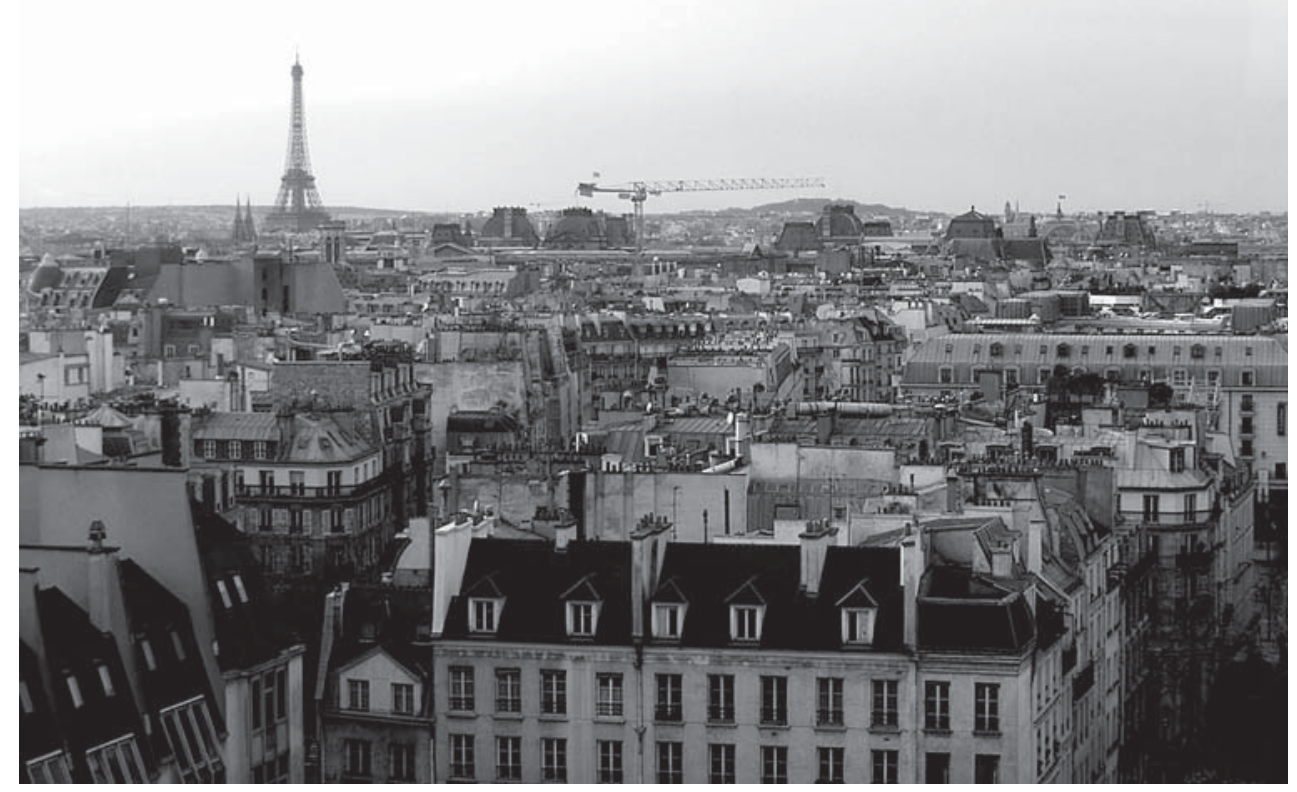

IRCAM необычен: главное здание находится на четырех спускающихся уровнях ниже площади Стравинского, смежной с Центром Жоржа Помпиду. Фонтан Стравинского украшен необычными автоматическими скульптурами, поливающими друг друга водой (фото 3). Подземное здание IRCAM было разработано тем же архитектором Роджерсом. Материалы конкретны и функциональны, сталь и

стекло; внутренний модерн с приглушенными серыми цветами и немногими деталями художественного оформления. Как все высокотехнологичные центры из-за потребности держать свои компьютеры непрерывно работающими, IRCAM управляется 24 часа и имеет вид научно-исследовательского института в большей степени, чем центра творчества и музыки (фото 4).

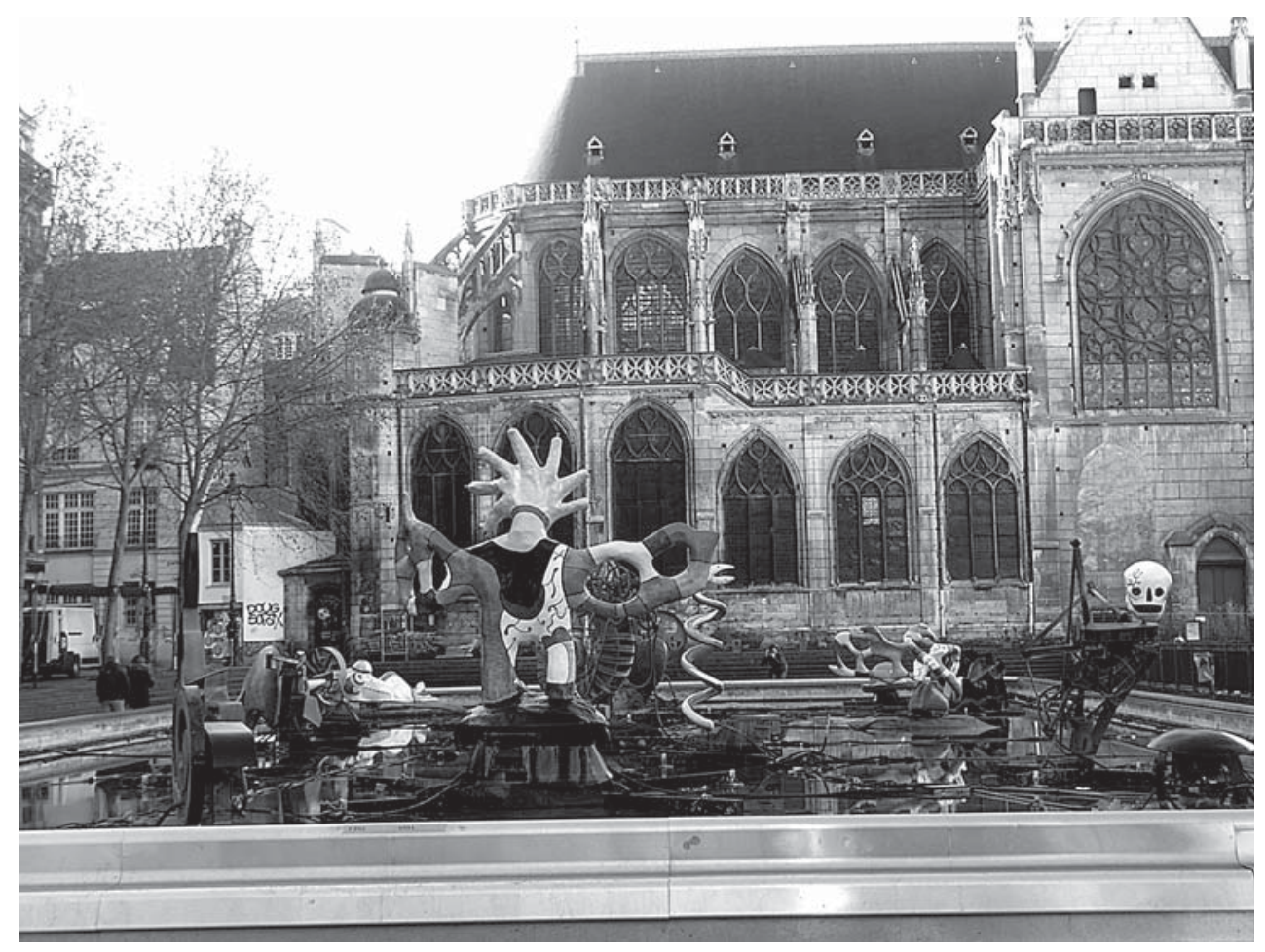

Фото 3. Площзадь И. Стравинского, фонтан И. Стравинского 


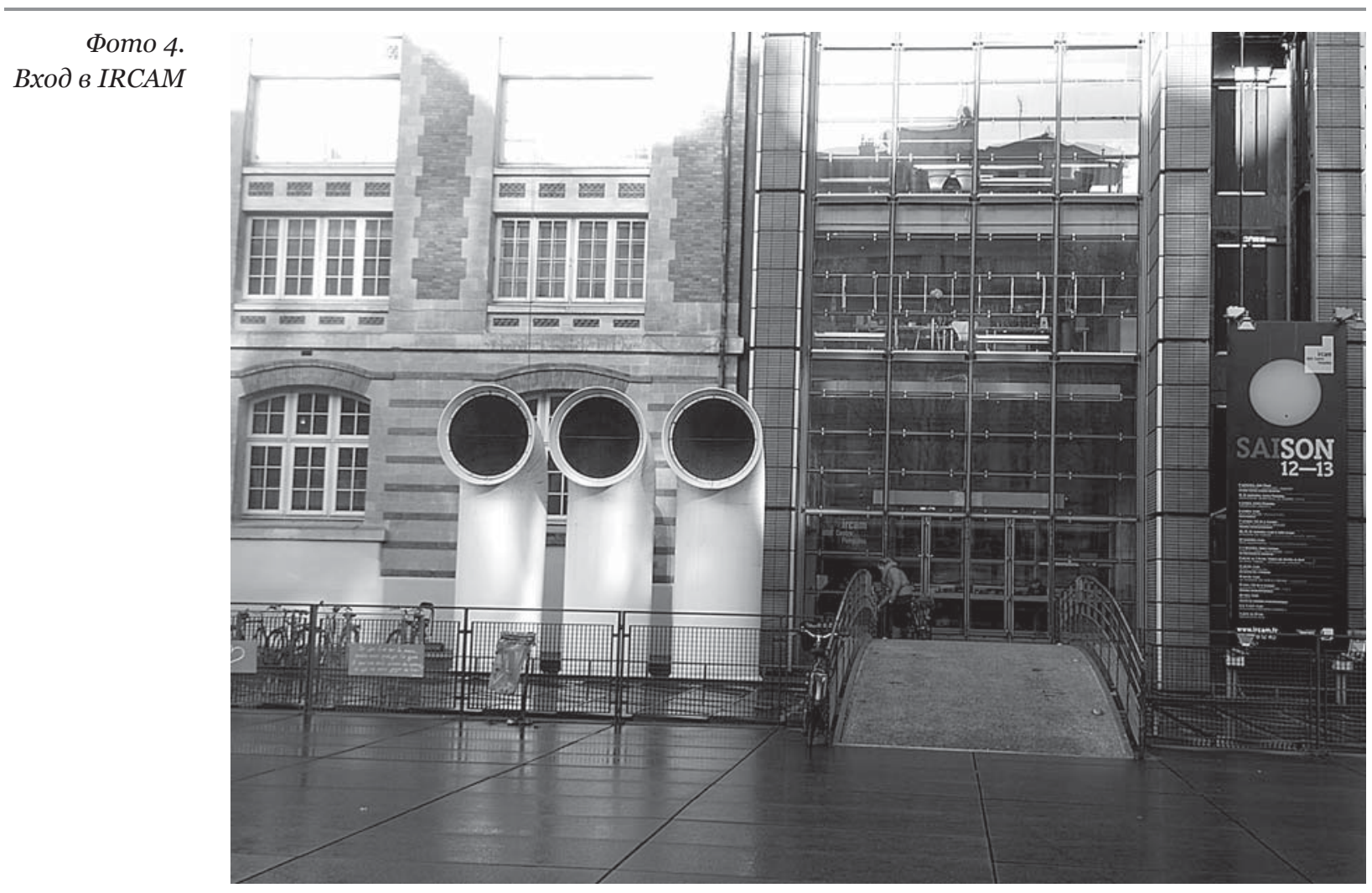

История IRCAM до 1984 года представляет три разных периода[25]. Первый, с 1970-х до 1977 гг., - планирование здания и развитие стратегии. Второй период, 1977-1980 гг., - открытие IRCAM, создание ансамбля InterContemporain, период целостного спланированного развития. Третья фаза - с 1980 по 1984 гг.

Третья фаза была начата внезапной перестройкой IRCAM Булезом в 1980 г. Это последовало за периодом внутренней неустойчивости, во время которой уехало большинство соруководителей. Причин было несколько. Главная из них: IRCAM непреклонно переориентировался к компьютерной музыке и вышел далеко за пределы тех проблем, которые были запланированы в пяти специальных отделах. Отделы: Электроакустический, Компьютер, Педагогика, Инструменты и Голос, Диагональ (координирующий отдел)[26]. Электроакустический сектор возглавлял итальянский композитор Лючано Берио, равный по положению Булезу. В действительности отделы были автономны и следовали своим собственным интересам. Так, Берио пригласил ученого соотечественника проектировать цифровой звуковой процессор в реальном времени, который впоследствии развился в главный компьютерный проект аппаратных средств IRCAM и достиг высшей точки вначале 1980-х гг. в производстве сильной машины, названной 4X.

IRCAM получает общественное и частное финансирование, но подавляющее большинство средств поступает от государства[27]. Его грант от Министерства культуры составляет приблизительно 70-80 процентов ежегодных фондов. Другой доход поступает из небольших грантов от Министерства исследования и из собственных банковских резервов IRCAM. Между 1982 и 1985 гг. полный ежегодный доход IRCAM составлял около 28-30 миллионов франков. Взамен государственных грантов статус IRCAM определяют, как некоммерческий исследовательский центр, обязанный приносить общественную пользу, и этим ограничен объем его коммерческого развития (до 1990 г.). Коммерческий доход IRCAM не превышал 15 процентов годовых доходов, таким образом, IRCAM юридически был оговорен развивать выгодные продукты, музыкальные или технологические. Частный патронаж вносит только небольшую часть дохода IRCAM. Существенная фигура здесь - швейцарский миллионер Пауль Захер, друг Булеза, в течение многих десятилетий «чемпион» авангардной музыки, который ежегодно жертвует IRCAM. 
Если говорить об обращении и продаже продукции IRCAM, то ни один из потенциальных источников дохода не имеет много прибыли[28]. Доход от продаж продуктов IRCAM (партитуры, концерты и билеты, конференции, кассеты, видео, и так далее) и от концертных туров IRCAM был небольшим. Зрители концертов IRCAM, как больших концертов с Булезом и хорошо известными фигурами, так и «юных» событий, не были постоянными. Концерты были самофинансируемы IRCAM; что касается научной работы, то она со всем академическим и общественно финансируемым исследованием свободно циркулировала среди сообщества исследований.

История производства цифрового звукового процессора в реальном времени $4 \mathrm{X}$, освещенная в книге Борн, поучительна в показе того, как, в конечном счете, удалось избежать получения прибыли для IRCAM[29]. С начала «индустриализации» дело 4X вызывало конфликты, настраивая отдел Администрации и Булеза против двух директоров команды 4X (директора Индустриализации 4X и директора Аппаратных средств 4X), которые хотели видеть, как 4X достигает рынка больших музыкантов вне IRCAM. Компания под названием Sogitec существенно заинтересовалась музыкальной мощностью $4 \mathrm{X}$. Компания производила части самолета и была близко связана с промышленностью обороны. Директор отдела Индустриализации продал $4 \mathrm{X}$ Sogitec, найдя способ использовать машину, чтобы моделировать шум самолета, и компания купила его: он стал основанием тренажера шумового полета. В июле 1984 Sogitec внезапно был принят гигантской компанией по защите Dassaultmaker, на основе высоких технологий выпускающей самолеты и оружие.

В конечном счете, Булез и администрация пришли к убеждению о приобретении нескольких 4XS, которые были необходимы для премьеры «Респонсория». IRCAM дал Sogitec опытный образец 4X как основание для производства, но взамен получил только четыре единицы 4XS и маленький лицензионный платеж. 4X был, таким образом, поднят ведущей французской компанией как полезный в промышленном отношении. Все же с тех пор компания Dassault / Sogitec не проявляла никакого интереса к рынку музыки; 4X никогда не был запущен в производство как коммерческий синтезатор музыки, и при этом эта машина не была даже произведена в таком ко- личестве, чтобы распределить ее для других компьютерных центров музыки.

Проектировщик 4X отказался дать Sogitec какие-либо письменные проекты для машины: компания должна была проектировать эту машину на пустом месте - это только один фактор в череде длинных задержек, в результате которых процессоры $4 \mathrm{X}$ прибыли от Sogitec поздно, практически к началу премьеры «Респонсория».

В своей известной статье «Технология и композитор» (1977), которая часто рассматривается как манифест IRCAM, Булез формулирует особенности культуры и идеологии IRCAM[30].

1. Принцип основания (тотальный сериализм, основанный на отрицании).

2. Потребность обеспечения музыки технологией и наукой.

3. Предприятие с новыми мультимедиями, СМИ, материалами и формами.

4. Сознательный авангардизм и стремление к постоянному новшеству.

5. Теоретизация.

6. Понятие необходимого отчуждения от широкой публики.

7. Антагонизм к торговле, к популярной музыке и культуре.

Эти особенности IRCAM формируют стадию «художественного модернизма» в его постсериальной традиции и в его контрапункте с музыкальным постмодернизмом.

В манифесте «Технология и композитор» Булез выделяет и более широкие исторические проблемы, требующие еще одного изменения: потребность превышать отрицание как основание нового музыкального языка. Это положение - своего рода комментарий относительно его прежней приверженности адорниановской эстетике и ее пределов. В конце 1960-х гг. Булез интерпретирует период тотального сериализма как закладывание основы нового музыкального языка (обязательно основанного на отрицании предшествующей тональной традиции). Однако он говорит, что за этим должен последовать переход к периоду «синтеза»[31], привлечению многих музыкальных, технологических и научных потоков прошлых десятилетий. Существенно его использование термина «синтез»: не только для характеристики поворота «от техники к языку»[32], но и в другом его значении - в значении электроакустического «звукового производства», центрального в его видении. 
$* * *$

В целом, Булез углубляет историческую перспективу в направлении прошлого и будущего (как в канторовской теории плюрализма типов бесконечного). Современная музыкальная композиция имеет богатое будущее: это подтверждает растущее число студий, центров, фестивалей и ансамблей современной и новой музыки. Среди зарубежных назовем французский камерный ансамбль InterContamporain (1976), американский Кронос-квартет (1973), нидерландский Аско-Шёнберг (2008), немец- кий Die Reihe (Ряд), швейцарские Collegium Novum Züric, PHOENIX Ensemble, UMS'n'JIP, украинский New Era Orchestra; среди отечественных - Московский ансамбль современной музыки (МАСМ, 1990), Студию новой музыки (1993), Галерею актуальной музыки (GAM-Ensemble, 2010) и многие другие. Однако период, который музыкальная композиция проходит сегодня, призывает композиторов, программистов, эстетиков и музыковедов исследовать настойчивее, чем раньше, проблемы, которые могли решаться на других стадиях истории более или менее стихийно.

\section{Примечания:}

[1] 1, c. 85 .

[2] $9,10,11$.

[3] 8, p. 81. Экспансивная книга Дж. Борн «Рационализация Культуры: IRCAM, Булез и институционализация музыкального авангарда» рассматривает хронику событий, бесед и мыслей Булеза в течение наблюдаемого периода времени в IRCAM (с 1973 по 1984 гг.).

[4] Ibid. p. 80-84.

[5] 9, p. 35-36.

[6] 13; см. также: 4 , с. 163-185.

[7] См.: 7, с. 85-87.

[8] Булез даже в своей стране принадлежит к космополитической личности. Однако его любовь к немецкой стране наполовину остается без ответа. С 1965 года Булез не выступал в Дармштадте с докладами. Его манят другие центры. С приходом К. Штокхаузена и Р. Штефана, ораторов и партнеров по дискуссии, Дармштадт изменяется, ибо вместе с ними теория попадает в руки профессионалов. Образуются другие центры музыкального авангарда, от США до Японии. См.: 12, S. 185.

[9] Об алгоритме анализа Второй фортепианной сонаты, о методах сериализма раннего Булеза см.: 4, С. 94-128; 5, C. $155-179$.

[10] 10, p. 443.

[11] 8, p. 83.

[12] Пер. с анг. языка см. в кн.: 4, с. 299-307.

[13] 10, p. 14

[14] Цит. по: 4, с. 299.

[15] 8, p. 83. Говоря о харизматической власти Булеза, Борн делает вывод: «Институт был результатом личного контакта между президентом и Булезом как ведущим художником-интеллектуалом» [Ibid. P. 73].

[16] В 1979-1991 гг. музыкальным руководителем ансамбля InterContemporain был венгерский композитор Петер Этвёш, автор оперы «Три сестры» по А. П. Чехову.

[17] «Респонсорий» заказан Юго-восточным радио для музыкального фестиваля в Донауэшингене. Композиция посвящена Альфреду Шлее, давнему другу композитора и известному директору Universal Edition в Вене, а также содержит скрытую ссылку на другого близкого друга, мецената Пауля Захера.

[18] См.: 4, с. 70-73.

[19] Зрелое решение булезовской проблемы материала развивалось между 1952 и 1957 гг., между «столбами», «Структурами 1» (1952) и Третьей фортепьянной сонатой (1957- ) в его композициях, и «Возможно» (Eventuellement) (1952) и «Alea» (1957) - в его статьях. Об эстетике, материале и новой форме Третьей фортепианной сонаты см.: 4, с. 186-210. О «Структурах 1а» см.: 3, с. 111-121.

[20] О концепте жестуализации Булеза см.: 11, S. 89-121. См. также: 6, с. 60-69; 7, с. 84-92.

[21] 8, p. 66. Работая в Bell Labs, в 1957 году М. Мэтьюс (1926-2011) создал «MUSIC», первую широко применяемую программу для электронной генерации звука, а в дальнейшем - первые электронные музыкальные инструменты.

[22] 15, p. 366.

[23] 8, p. 83-84. 
[24] 14.

[25] 8, p. 103.

[26] Ibid. P. 103.

[27] Ibid. P. 107.

[28] Ibid. P. 108.

[29] Ibid. P. 110-111.

[30] 10, p. 486-494.

[31] Ibid. P. 463.

[32] Поворот «от техники к языку» осуществлен О. Мессианом в его трактате «Техника моего музыкального языка» (1942): 2.

\section{Библиография:}

1. Деррида Ж. Маркс и сыновья / Пер. с франц. Д. Новикова. - М.: Logosaltera, 2006. -C. 85.

2. Мессиан О. Техника моего музыкального языка / Пер. с франц. и коммен. М. Чебурнкиной. - М.: Греколатинский кабинет Ю. А. Шичалина, 1994. - 128 с.

3. Окунева Е. Г. Анализ серийной и сериальной музыки / учеб. пособие. -Петрозаводск, 2012. - С. 111-121.

4. Петрусева Н. Пьер Булез. Эстетика и техника музыкальной композиции. - М., 2002. - С. 70-73, 94-128, 155-179, 163-185, С. 186-210, 299-307.

5. Петрусева Н. Музыкальная композиция XX века: структуры, методы анализа. В 2-х частях. Часть 1. Пермь, 2006. - С. 155-179.

6. Петрусева Н. Концепт «Композиция и ее жесты» Пьера Булеза // Текст художественный: грани интерпретации: Сб. науч. статей по материалам международной конференции / Петрозаводская гос. консерватория им. А. К. Глазунова. - Петрозаводск, 2013. - С. 60-69.

7. Петрусева Н. «Система координат» в музыке П. Булеза и С. Шаррино: к проблеме эстетического осмысления музыкальной композиции // Обсерватория культуры, 2015. № 2. - С. 84-92.

8. Born G. Rationalizing culture. IRCAM, Boulez, and the Institutionalization of Musical Avant-Garde. Univ. of California press. - Berkeley and Los Angeles, California, 1995. - P. 66, 73, 81, 80-84, 103, 107, 108, 110-111.

9. Boulez P. On music today / trans. by S. Bradshaw and R. Bennett. - Cambridge, Mass.: Harvard University Press, 1971. - P. 35-36.

10. Boulez P. Orientations. Collected Writing's by Pierre Boulez edited by Jean-Jacques Nattiez. Trans. By Martin Cooper. - Harvard Univ. Press. Cambridge, 1986. - P. 14, 443, 486-494.

11. Boulez P. Leitlinien. Gedankengänge eines Komponisten. - Bärenreiter. Metzler. Kassel, 2000 - S. 89-121.

12. Hirsbrunner T. Pierre Boulez und sein Werk. - Laaber: Laaber-Verlag, 1985. - S. 185.

13. Koblyakob L. Pierre Boulez: A World of Harmony. - Chur. London. Paris: Harwood academic publishers, 1986. - 130 p.

14. Musée National d'art Moderne - Centre Pompidou. Paris: SCALA GROUP, 2011. 96 p.

15. Walters D. The Aesthetics of Pierre Boulez. Department of Music University of Durham, 2003-2004. - P. 366.

\section{References (transliterated):}

1. Derrida Zh. Marks i synov'ya / Per. s frants. D. Novikova. - M.: Logosaltera, 2006. -S. 85.

2. Messian O. Tekhnika moego muzykal'nogo yazyka / Per. s frants. i kommen. M. Cheburnkinoi. - M.: Grekolatinskii kabinet Yu. A. Shichalina, 1994. - $128 \mathrm{~s}$.

3. Okuneva E. G. Analiz seriinoi i serial'noi muzyki / ucheb. posobie. -Petrozavodsk, 2012. - S. 111-121.

4. Petruseva N. P'er Bulez. Estetika i tekhnika muzykal'noi kompozitsii. - M., 2002. - S. 70-73, 94-128, 155-179, 163-185, S. 186-210, 299-307.

5. Petruseva N. Muzykal'naya kompozitsiya KhKh veka: struktury, metody analiza. V 2-kh chastyakh. Chast' 1. Perm', 2006. - S. 155-179.

6. Petruseva N. Kontsept «Kompozitsiya i ee zhesty» P'era Buleza // Tekst khudozhestvennyi: grani interpretatsii: Sb. nauch. statei po materialam mezhdunarodnoi konferentsii / Petrozavodskaya gos. konservatoriya im. A. K. Glazunova. - Petrozavodsk, 2013. - S. 60-69.

7. Petruseva N. «Sistema koordinat» v muzyke P. Buleza i S. Sharrino: k probleme esteticheskogo osmysleniya muzykal'noi kompozitsii // Observatoriya kul'tury, 2015. № 2. - S. 84-92. 
8. Born G. Rationalizing culture. IRCAM, Boulez, and the Institutionalization of Musical Avant-Garde. Univ. of California press. - Berkeley and Los Angeles, California, 1995. - R. 66, 73, 81, 80-84, 103, 107, 108, 110-111.

9. Boulez P. On music today / trans. by S. Bradshaw and R. Bennett. - Cambridge, Mass.: Harvard University Press, 1971. - R. 35-36.

10. Boulez P. Orientations. Collected Writing's by Pierre Boulez edited by Jean-Jacques Nattiez. Trans. vy Martin Cooper. - Harvard Univ. Press. Cambridge, 1986. - R. 14, 443, 486-494.

11. Boulez P. Leitlinien. Gedankengänge eines Komponisten. - Bärenreiter. Metzler. Kassel, 2000 - S. 89-121.

12. Hirsbrunner T. Pierre Boulez und sein Werk. - Laaber: Laaber-Verlag, 1985. - S. 185.

13. Koblyakob L. Pierre Boulez: A World of Harmony. - Chur. London. Paris: Harwood academic publishers, 1986. $-130 \mathrm{p}$.

14. Musée National d'art Moderne - Centre Pompidou. Paris: SCALA GROUP, 2011. 96 p.

15. Walters D. The Aesthetics of Pierre Boulez. Department of Music University of Durham, 2003-2004. - P. 366. 